\title{
Cultivation of Occupational Quality to Higher Vocational Students Based on the Employment-Oriented
}

\author{
Li Guofeng \\ Shandong Transport Vocational College \\ Weifang, Shandong
}

\begin{abstract}
Improving the Vocational College Students' employment quality, training high-quality and high-skilled talents to meet the employing units' double requirements to the profession and quality of higher vocational colleges. We should be based on enterprises' needs, take the employment as the guidance, cogently improve higher vocational students' occupational quality and shorten the gap between supply and demand.
\end{abstract}

Key words: higher vocational education; higher vocational students; occupational quality; enterprises' needs

\section{INTRODUCTION}

With the rapid development of world science, technology and economy, the majority of enterprises require the employee have strong occupational quality. Higher vocational education is "to take serve as the purpose, to take employment as the direction, to take training the high-quality skilled talents meeting the needs of fist-line such as production, management and service as the goal ". To take the employment as the guidance is to construct the training "overpass" of occupational quality for higher vocational students. To strengthen the main occupational competitiveness of the Vocational College Students - cultivation of occupational quality is not only the need of reality, but also the base of future careers' success for higher vocational students. How to improve the quality of higher vocational college students and make them meet enterprises' needs has become an important issue in front of us.

Firstly, let us talk from the enterprises' demands to higher vocational college students and several problems deserving to be concerned. We will try to find the two entry points, analyze the origin of the problems, take proper measures to shorten the gap between the two sides of supply and demand and then solve the problems.

\section{ENTERPRISES' OCCUPATIONAL QUALITY REQUIREMENTS TO Higher VOCATIONAL COLLEGE STUDENTS}

Through the investigation, we found that in many enterprises, the problems of affecting the development of enterprises is no longer the funds and equipment, but the lacking of high occupational quality staff. The enterprises' quality requirements to higher vocational college students are mainly the following three aspects:

\section{A Requirements to Occupational Skills \\ Solid and broad professional knowledge is the}

foundation, and excellent technical ability is the key. Enterprises hope that when going to their posts, the graduates can be qualified for a certain post work as early as possible. They can embody their professional knowledge with "moving hands, mouths and brains, which is called “occupational ability”.

\section{B Requirements to Moral Quality}

Loving and respecting their jobs, hard working, being good at communication, solidarity and cooperation are enterprises' basic requirements to higher vocational graduates. Some entrepreneurs say directly, now we don't doubt that college students can do a certain job skillfully, but we pay more attention to their characters and moral qualities. Many enterprises, especially foreign enterprises, when recruiting employees, always put moral quality on the first place and don't take academic achievement as the only standard. When visiting the enterprises, we found the most that enterprises' managers or personnel managers have complained about is the moral qualities of employees. A senior CEO refers that college students refuse to go to workshop, worry about hardship and complain about treatment, and they need others to teach them how to conduct themselves and business, which cause some difficulties to enterprises.

\section{Requirements to Pioneering and Innovative Spirit}

The majority of higher vocational graduates is on the "team leader" position and must bear the burden of production innovation. "Innovation is in the grass". To the enterprises' character, "team leader" is the main character of innovation. According to the enterprises' requirements to the "team leader's" quality, the vocational college students we have fostered at present can only meet the 1/3 requirement. And many higher vocational students fall into the general operating staff for their poor qualities, which increases the modern enterprises' thirst to qualified higher vocational graduates.

\section{SEVERAL PROBLEMS DESERVING TO BE CONCERNED AND EXISTING ON THE VOCATIONAL COLLEGE STUDENTS}

According to the investigation to the freshmen, the college senior students and the trainees, we find that the problems existing on them are as following:

\section{A Etiquette andCcivilization Consciousness are Insufficient}

The main performances are lacking of good manners in 
getting along with people, speaking and behaving and indifferent social morality consciousness. From this point, I have a very deep experience, when meeting my students on campus, I often give them a smile, but they pay no heed and take me as a passer-by stranger. Many teachers often experience this "hot face being on a cold ass". The phenomenon of littering, refusing to offer seats to the elder ant etc. is everywhere.

\section{B Dedication Spirit is not Strong}

Their occupational ideals are separated from themselves and the social reality. A considerable number of students look down the grass-roots work and the first-line production post, so they lack professional technology and intensive study and are relatively poor in professional quality. From the feedback of a lot of enterprises, our higher vocational graduates do not have a strong sense of dedication. Some students are often "job-hopping”. They often change jobs four or five times one year and think the other grass is always greener. And they often compare wages and treatment with others. Some students think that they work for a boss, the boss must repay them benefit, a higher salary and bonuses. The students also worry about a petty profit. If the enterprise does not meet their requirements, they immediately resign, who lack the spirit of dedication

\section{Lack of Love and Honesty}

Some students are self-centered and their outlooks on life advocate ego. And they only take care of themselves, emphasize self-realization and lack of love to families, others and society. From the feedback of a lot of enterprises, higher vocational graduates' occupational qualities are quite worrying. Many graduates do not set their minds at work, be fastidious but incompetent and ambitious and lack of integrity and sense of social responsibility. Some graduates without faith promise and then deny in succession and don't perform the agreement signed with employers. The phenomenon of default often occurs.

\section{Vulnerable Psychology}

Some college students are not enough in interpersonal communication, lacking of social adaptability. Their psychological quality is poor and the ability of bearing trouble is not strong, so it is difficult for them to correctly deal with various complicated situations. When facing setbacks and being hit by troubles, they get very easily psychological disorders, and even go to bay. Some of them are pessimistic and world-weary, and some even heed for their doom.

\section{STRENGTHEN THE EDUCATION OF OCCUPATIONAL QUALITY TO HIGHER VOCATIONAL COLLEGE STUDENTS AND ADAPT TO ENTERPRISES’ REQUIREMENTS}

Occupational quality is the base of skills and knowledge. In terms of education, the training of occupational quality is more difficult than the teaching of skills and knowledge. Because occupational quality can be improved only through classroom teaching and doing homework, which are very complex and need a long-term comprehensive training and influencing.

Higher vocational colleges must adhere to the educational idea of basing on requirements, draw lessons, establish the tenet of "using tomorrow's technology to train today's students and serving for future." and take the training of advanced technology as the characteristic of running a school. Colleges take enterprises as the most important customer. Professions' setting depends on regional industrial structure, specification of training students depends on the employment's needs, colleges' management keep to enterprises' standard and bring the knowledge learning now into correspondence with the future jobs. Higher vocational colleges should adapt to enterprises' requirements to personnel quality. We must do a good job on school-enterprise cooperation being based on enterprises' needs, so the following aspects must be done:

\section{A Pay Attention to the Education of Basic Quality}

Actively carry out the project of "three change" to every new-born college student shortly after admission: the role's transition, the thoughts' transition and the images' transition. Make them from ideology realize the necessity of cultivating civilization and good qualities. And try to make them form the habit of civilization and good manners and establish the good civilized and upward image.

Moral cultivation must start from the most basic thing. We should cultivate students' healthy psychology, healthy personality and the way of getting along with people.

$B$ Attach Importance to the Education of Employment, Entrepreneurship and Dedication

The occupational colleges, we should also focus on strengthening the students' education of employment and entrepreneurship, guiding students to establish a correct view of employment, educating students to put their ideals and social development and the needs of the motherland together. Now graduates are difficult to finding jobs, and I think there are a lot of factors. They don't want to the places needing them and the places that they want to go don't need them. And they don't take entrepreneurship into consideration. We should train students from waiting job opportunities to look for job opportunities and to create jobs. Therefore we should attach importance to the training to students' entrepreneurial skills. In addition, we also should educate students to love their own professions and give themselves a clear position. Students should neither reach for what is beyond their grasp nor belittle themselves, and they should do every work with heart and soul.

\section{Attach Importance to the Education of Students' Love and Honesty}

Win the heart with heart, and win the love with love. Making students have love should first make them love their 
parents. If a person doesn't love his parents, talking about loving others is empty. Love is the base of inducting emotion, and using the power of love to educate students will get the students' trust. Teachers must love, respect and trust every student sincerely. Then let us talk about honesty. Honesty is the thing that everyone can have. It depends on the morality's power to inner nature. There is a Chinese proverb, One tael heavy sincerities are equal to one ton heavy cleverness. Honesty is not only a kind of attitude, but also a kind of personality power. The CEO of General Electric of USA said, "Why our company keeps its flag flying for one hundred years long, the central competence is honest ". In the same way, if there is no credibility, we will not see the Mercedes-Benz.

\section{Enhance Students' Professional Skills}

Higher vocational colleges should take enterprises' needs as the guides, deepen the teaching reform, joint together the demands of enterprises' posts, compare the national occupational standard, determine and adjust the professional training objectives and curriculum, develop training programs together with cooperative enterprises and improve the professional skills of higher vocational college students. At the same time, we should highlight the practical teaching, emphasis on the training to practical skills and take it as the root of running a college improving students' professional and technical quality, so that students can be skilled in some kind of work.

\section{E Strengthen the Teamwork and Raise Global Awareness}

We can combine occupational interests to set up all kinds of associations and groups to arouse students' initiative, activity and autonomy and let students choose a leader according to their qualities and abilities and undertake reasonably the jobs, then work out feasible action plan, make guide-raining step with self-educating, establish art groups to cultivate students' expertise and improve students' aesthetic ability. And we can also foster students' noble spirits, establish students' bands, dancing team and college choirs and cultivate students' cultural and artistic quality, ability of communication and teamwork spirit.

In conclusion, being based on enterprises' needs, improving the occupational quality of Higher Vocational Colleges, Higher Vocational Colleges have a long way to go.

\section{CONCLUSION}

In short, the implementation of education of occupational quality is a systematic project, which needs the cooperation of colleges, enterprises and society. We should set from the construction of course system, deepen the teaching reform, develop rich and colorful extracurricular activities and other aspects, guide students to know themselves, explore career, learn to plan their own learning and career scientifically and reasonably, further enhance the consciousnesses of occupation, honesty, team and innovation, develop good occupational moral quality and civilized behavior, improve students' comprehensive quality and lay a solid foundation for achieving sustainable development of higher vocational college students.

\section{REFERENCE}

[1] Tian Jianguo, "New Ideas of Modern University," Taishan Press, Jan. 2005

[2] Jiang Guoliang, "Several Considerations on Carry on Education of Quality in Higher Vocational Colleges,” Journal of Jiangsu Radio and TV University, Jan. 2006

[3] Zhou Xiyu and Ling Boxun, Li Xiping, "On the Training to Comprehensive Occupational Quality of Higher Vocational College Students," Journal of Yueyang Vocational Technical College, Aug. 2006

[4] Zhao Yali, "On Education's Content and Countermeasures of Higher Vocational College Students,” Journal of Shanxi Economic Management Institude, Mar. 2012

[5] Xiao Yali and Yi Yanping, Yu Lu, "Cultivation of Occupational Quality to Higher Vocational Students Based on the Employment-Oriented,” Shandong Textile Economy ,Oct. 2012. 